\title{
Pseudemys concinna (Le Conte 1830) - River Cooter
}

\author{
Joseph P. W ARD $^{1}$ AND DALE R. JACKSON ${ }^{2}$ \\ ${ }^{1} 6899$ South Highway A1A, Melbourne Beach, Florida 32951 USA [jpwtct@cfl.rr.com]; \\ ${ }^{2}$ Florida Natural Areas Inventory, Florida State University, \\ 1018 Thomasville Road, Suite 200-C, Tallahassee, Florida 32303 USA [djackson@fnai.org]
}

Summary.-Pseudemys concinna (Family Emydidae) is a large,riverine turtlethat occurs in relatively dense populations throughout the eastern and southern parts of the United States. Currently generally recognized subspecies include $P$. c. concinna and $P$. c . suwanniensis. Studies of diet, reproduction, and population demography have focused chiefly on Florida populations. There is little reason to be concerned about the species' survival, although no definitive studies have been conducted to establish population dynamics or statistics across its entire distribution. Further study is necessary to determine whether specific protective measures beyond those already in place in some states are needed.

Distribution. - USA. Southeastern USA from Virginia through Florida to eastern Texas.

Synonymy. - Testudo concinna Le Conte 1830; Emys (Testudo) concinna; Terrapene concinna; Clemmys (Clemmys) concinna; Pseudemys concinna; Ptychemys concinna; Chrysemys concinna; Emys annulifera Gray 1830; Trachemys annulifera; Emys hieroglyphica Holbrook 1836; Pseudemys hieroglyphica; Ptychemys hieroglyphica; Clemmys hieroglyphica; Chrysemys hieroglyphica; Pseudemys floridana hieroglyphica; Pseudemys concinna hieroglyphica; Chrysemys concinna hieroglyphica; Emys labyrinthica Emys mobilensis Holbrook 1838; Emys mobiliensis; Ptychemys mobiliensis; Clemmys mobilensis; Pseudemys mobiliensis; Pseudemys mobilensis; Chrysemys mobiliensis; Clemmys mobiliensis; Pseudemys floridana mobiliensis; Pseudemys concinna mobilensis; Pseudemys floridana mobilensis; Pseudemys concinna mobiliensis; Chrysemys concinna mobilensis; Duméril and Bibron 1851; Clemmys labyrinthica; Pseudemys labyrinthica; Chrysemys labyrinthica; Ptychemys hoyi Agassiz 1857; Pseudemys concinna hoyi; Pseudemys floridana hoyi; Chrysemys floridana hoyi; Emys orthonyx Wied 1865; Pseudemys elonae Brimley 1928; Pseudemys vioscana Brimley 1928; Pseudemys concinna metteri Ward 1984.

SuBsPECIES. - Two currently recognized: Pseudemys concinna concinna (Eastern River Cooter) (synonyms: Pseudemys floridana concinna; Chrysemys concinna concinna); and Pseudemys concinna suwanniensis (Suwannee Cooter) (synonymy: Pseudemys floridana suwanniensis Carr 1937; Chrysemys concinna suwanniensis; Pseudemys suwanniensis).

STATUS. - IUCN 2007 Red List: Not Listed (= Least Concern, LR/lc) (assessed 1996, needs updating); CITES: Not Listed; US ESA: Not Listed.

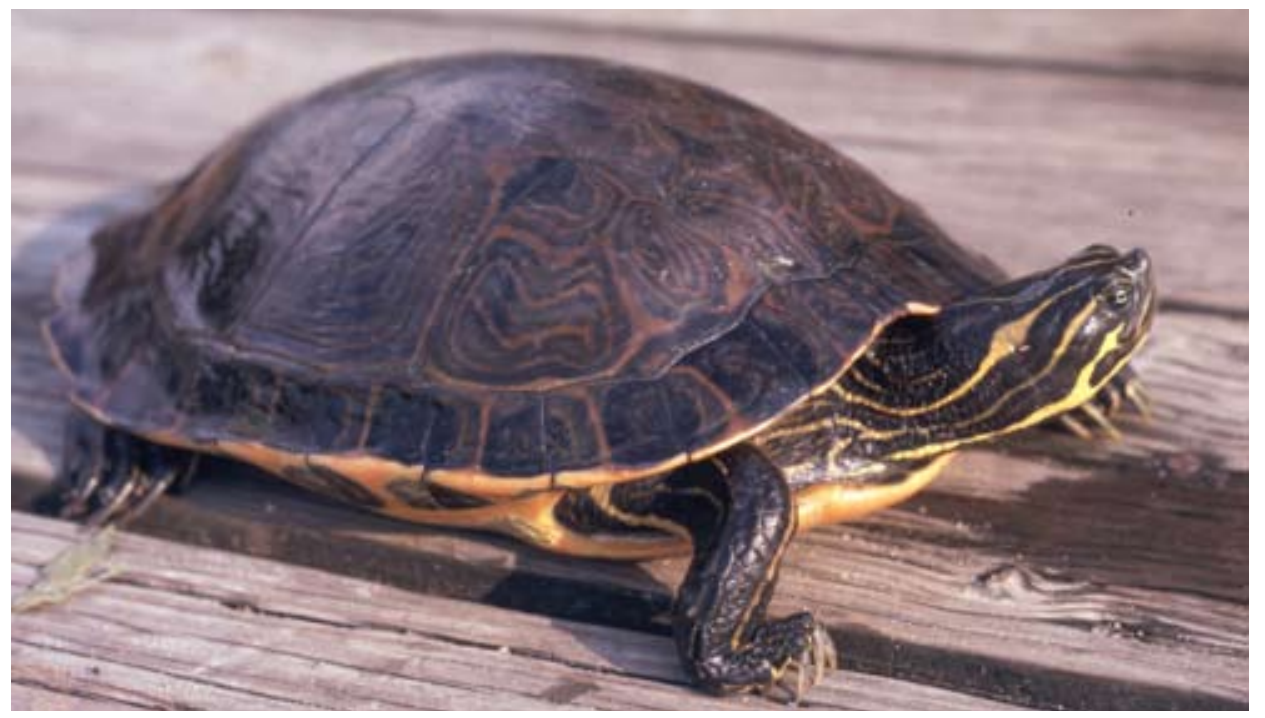

Figure 1. Adult female Pseudemys concinna concinna from Spring Creek, Decatur Co., Georgia, USA. Photo by Peter A. Meylan (from Jackson 2006). 


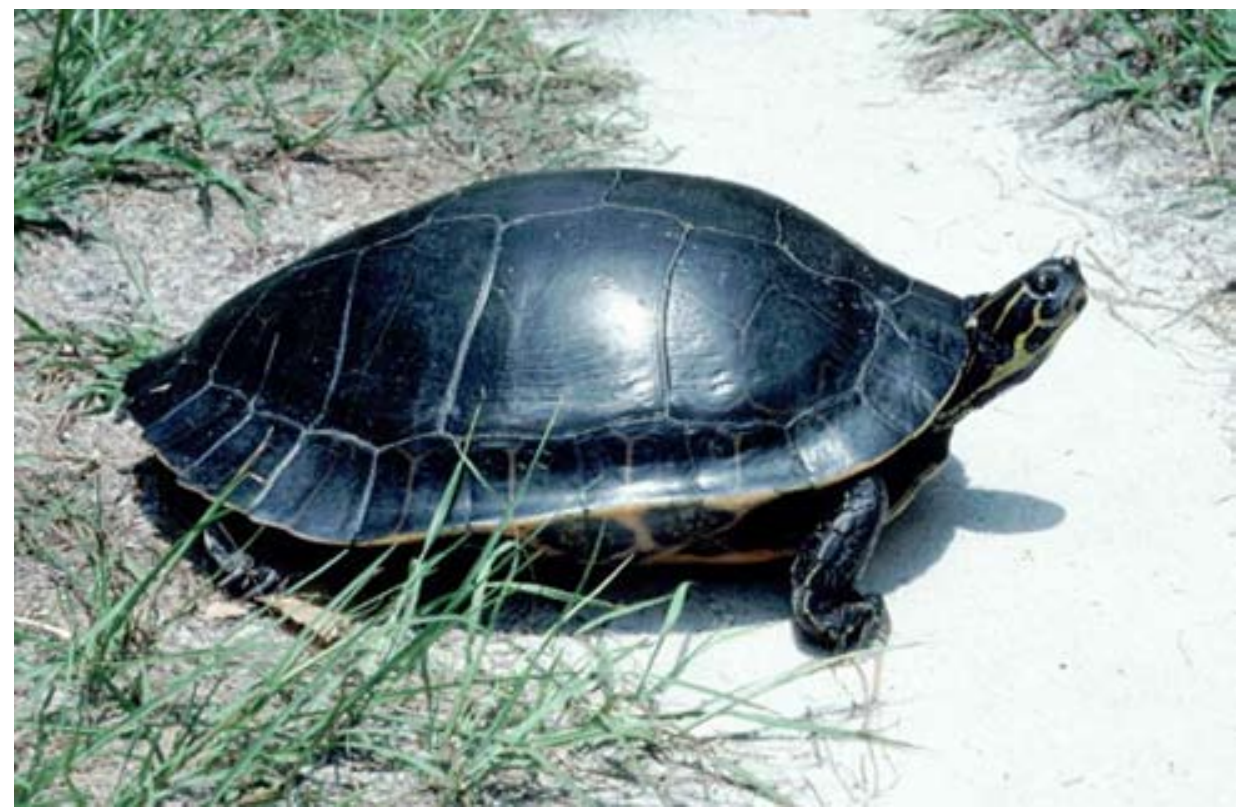

Figure 2. Adult female Pseudemys concinna suwanniensis, from Wakulla River, Wakulla Co., Florida, USA. Photo by Dale R. Jackson (from Jackson 2006).

Taxonomy. - The systematic relationships of river cooters, Pseudemys concinna, are complex and controversial. We recognize the species as being closely related to, but distinct from, Florida and peninsular cooters, Pseudemys floridana (Ward 1980, 1984; Jackson 2006; Thomas and Jansen 2006). Together, these species form a single lineage that has been referred to as the subgenus Pseudemys (Pseudemys), which also contains Texan populations formerly allied with river cooters but now recognized as full species, P. gorzugi and P. texana. Pseudemys

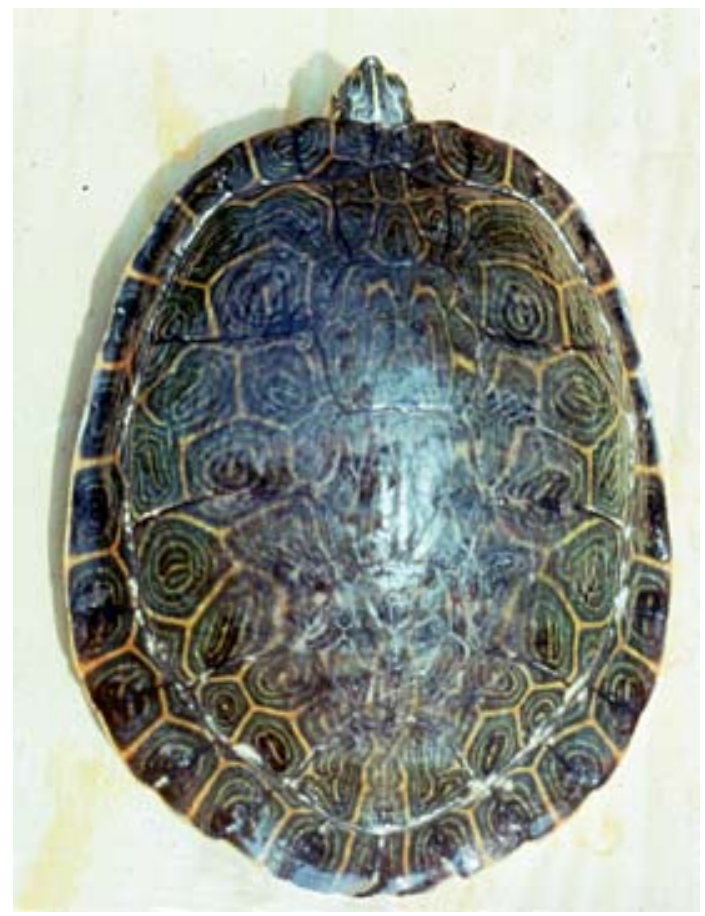

Figure 3. Pseudemys concinna concinna from Flint River, Albany, Madison Co., Alabama, USA. Photo by Joseph P. Ward. alabamensis, $P$. nelsoni, and $P$. rubriventris belong to a second lineage, the rubriventris series, sometimes referred to as subgenus Pseudemys (Ptychemys) (Ward 1980, 1984; Seidel 1994). Previously, anywhere from five to seven subspecies of $P$. concinna were recognized (concinna, gorzugi, hieroglyphica, metteri, mobilensis (mobiliensis), suwanniensis, and texana), Ward (1980) recognized only three - concinna, hieroglyphica, and suwanniensis. Although Ward (1984) proposed relegating P.c. mobiliensis to the synonymy of P. c. hieroglyphica, the former was still recognized by Ernst and Barbour (1989). Based on the lack of distinctive morphological characters, Seidel (1994) subsumed the names hieroglyphica, metteri, and mobiliensis into P. c. concinna; at the same time, he elevated suwanniensis, (following the suggestion of Frost and Hillis 1990), which he believed to be geographically disjunct, to specific status. Jackson (1995) provided

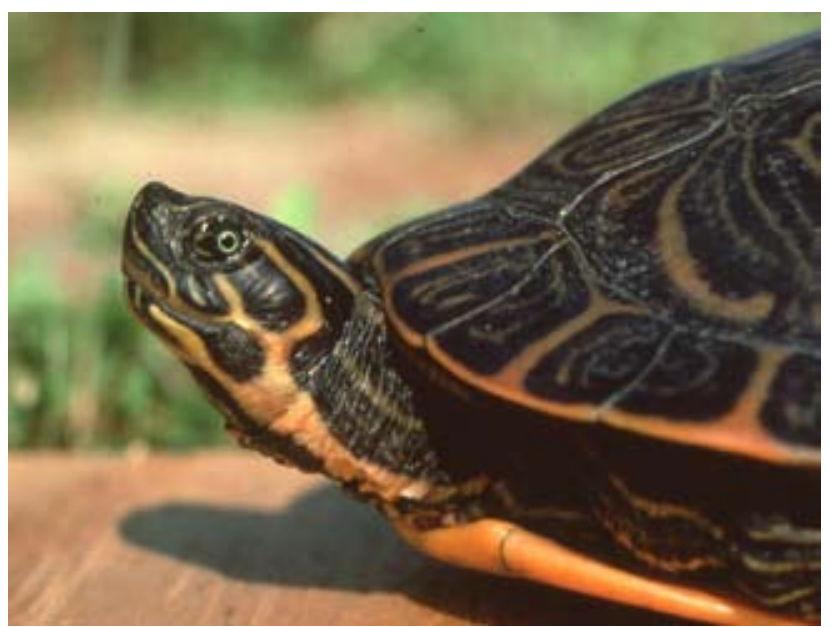

Figure 4. Pseudemys concinna concinna from Cahaba River, Bibb Co., Alabama, USA. Photo by Joseph P. Ward. 


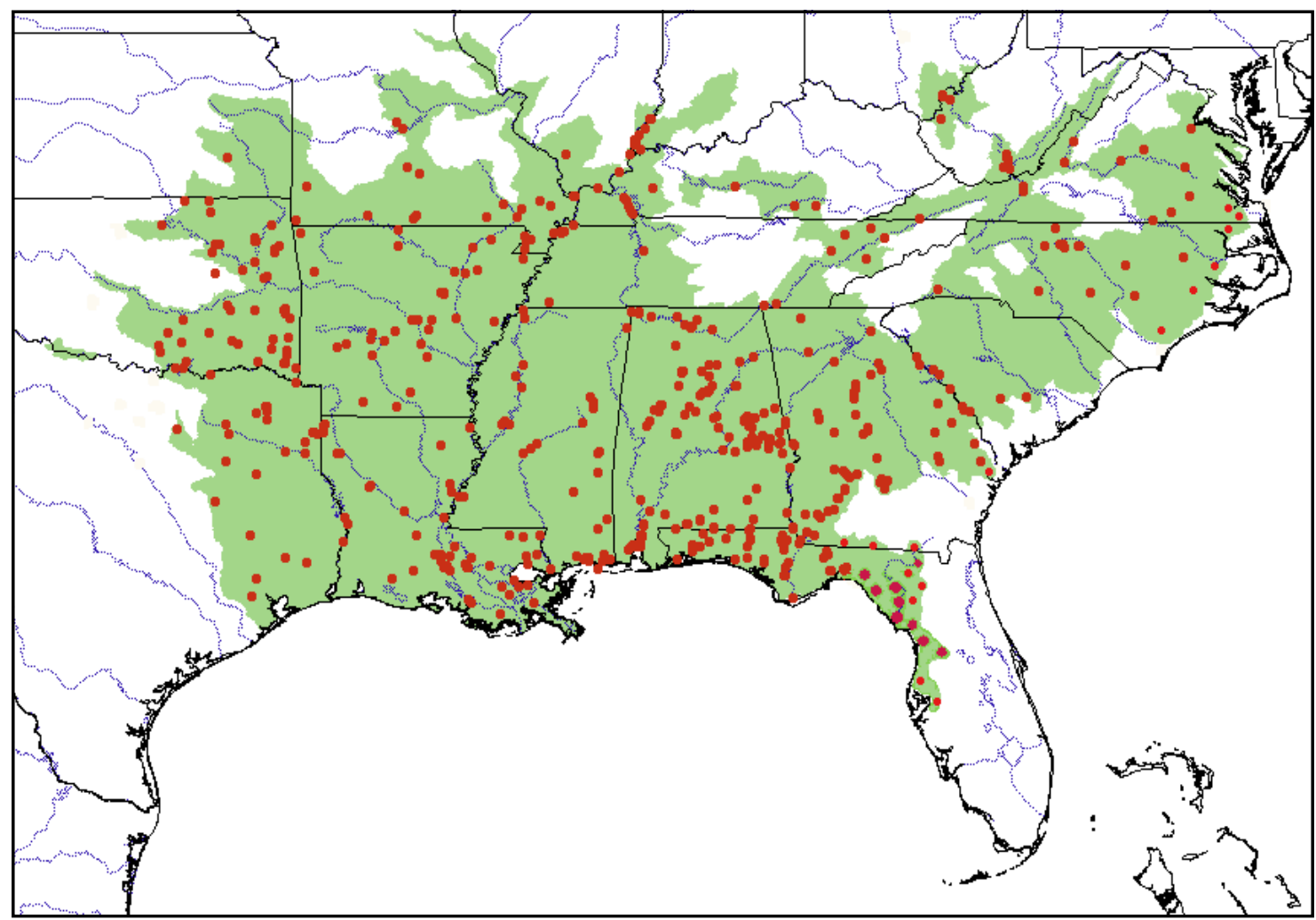

Figure 5. Distribution of Pseudemys concinna in southeastern USA. Red points = museum and literature occurrence records based on Iverson (1992) plus more recent and authors' data; green shading = projected distribution based on GIS-defined hydrologic unit compartments (HUCs) constructed around verified localities and then adding HUCs that connect known point localities in the same watershed or physiographic region, and similar habitats and elevations as verified HUCs (Buhlmann et al., unpubl. data), and adjusted based on authors' data.

geographic evidence that suwanniensis was not disjunct and returned it to a subspecies of P. concinna, a conclusion accepted by Seidel and Dreslik (1996). Jackson (2002) subsequently provided additional geographic as well as morphological data in further support of this assignment. Ernst and Barbour's (1989) recognition of P. texana as distinct from $P$. concinna has gained general acceptance in recent treatments (Dixon 1987; Conant and Collins 1991; Seidel 1994). Ernst (1990) elevated the former subspecies gorzugi to species status based on allopatry and lack of intergradation, although further study of this relationship is needed. As a result, most experts (e.g., Meylan 2006) now recognize only two subspecies of $P$.concinna, a wide-ranging $P$. c. concinna and a narrowly restricted $P$. c. suwanniensis.

In some parts of the common range of $P$. concinna and $P$. floridana, including all of Florida, the two taxa are in microsympatry and behave as distinct species. In other areas, particularly in the northeastern and western portions of the ranges, the relationship is less clear (Dundee and Rossman 1989; Seidel and Palmer 1991, Seidel 1994).

Description. - River cooters are large aquatic turtles that reach $42 \mathrm{~cm}$ in carapace length (CL). Males are slightly smaller than females when mature, reaching $30 \mathrm{~cm}$ CL. External sexual differences are limited to the slightly higher profile of females, and the significantly longer, thicker tail and extremely elongated foreclaws of males (Huestis and Meylan 2004).
In eastern populations, the carapace usually has a posteriorly facing ' $\mathrm{C}$ '-shaped marking on the posterior edge of the second and third pleural scutes. In western populations, this mark is often reduced to a nearly straight line or small whorls; however, in a large number of specimens the upper posterior whorl of the third pleural forms a ' $C$ ' that is cut off by the interscute seam with pleural IV. Additionally, in western populations each carapacial scute has a pattern of yellow lines and whorls on a brown to greenish background. The background color may have intense reddish brown pigment or may be very dark, nearly black in some populations such as in the Suwannee River, Florida. Marginal scutes usually have a straight to slightly curved medial yellowish line.

The plastron is yellow to bright orange-red, usually with a variably developed dark pattern that follows the interscute seams; the pattern is especially intense in juveniles. In some specimens, the pattern is confined to the anterior plastral lobe. Northern populations may have immaculate plastra but usually have some black markings on the inguinal scute. In contrast, specimens of $P$. floridana typically have an immaculate pale yellow plastron and no dark mark on the inguinal, although some may have a disorganized dark pattern on parts of the plastron. The ventral aspect of the bridge of P. concinna usually has a dark line or parallel dark lines running antero-posteriorly near the confluence with the plastron. 
In older specimens, particularly males, the stripe may be broken into disorganized spots.

The entire shell may be profused with red pigments. This rubrivescence occurs in most populations but is more highly developed in populations from Oklahoma and parts of Texas, and less pronounced in populations in North Carolina, Georgia, southern Alabama, and Florida.

The head is striped with yellow lines. The postlabial stripe has two branches: an infralabial running along the mandible, and a supralabial running along the maxilla. The lateral stripe is usually the widest head stripe and extends to the orbit. Usually there is a sagittal stripe. The dorsal stripes usually dominate the dorsum of the head, although these may fade with age or be broken into spots in some specimens. The ventral stripes usually meet to form a symphyseal line to the chin. These may expand irregularly with a great variation among individuals within any population.

Foreleg stripes are well organized in branching or straight patterns. The prevalent pattern throughout the range of the species has the innermost stripe branching above the elbow joint, sending a middle branch onto the forearm where it again branches. The hindleg stripes form continuous lines along the dorsum of the leg all the way to the toes. The legs are mostly black in P. c. suwanniensis.

Distribution. - Pseudemys concinna is principally a turtle of the rivers of the southeastern USA, although its range extends northward and westward from this region. The species occurs in the piedmont and coastal plain from Virginia, south and west across Georgia to western Oklahoma; north into Kansas, Missouri, Illinois, and Ohio; and south into west-central Florida and northeastern Texas to the Gulf of Mexico.

Habitat and Ecology. - Detailed studies of habitat preferences have not been conducted for most populations, with the exception of the restricted population of P.concinna in the New River, West Virginia (Buhlmann and Vaughan 1991). Generally, P. concinna prefers permanent flowing water with abundant submergent vegetation and areas of deep holes or expanses exceeding one meter water depth. Large populations are found in clear, deep streams (depth exceeding $5 \mathrm{~m}$ ), or those with a clear bottom boundary layer under a darker stained or silty upper layer. Other large populations are found in clear lakes, such as White Lake in North Carolina. Clear water is preferred because it is more apt to harbor dense stands of vegetation that comprise the majority of the species' food.

In the New River of West Virginia, P. concinna is found in pool habitats characterized by slow currents, shallow water less than $2 \mathrm{~m}$ deep, aquatic vegetation, and abundant basking sites (Buhlmann and Vaughan 1991). In White Lake, North Carolina, P. concinna once was very abundant. Although average lake depth was $4 \mathrm{~m}$, most turtles were usually in shallower water, to $1.3 \mathrm{~m}$, and within $10 \mathrm{~m}$ of shore, where vegetation was abundant. In the North Fork River, Missouri, $P$. concinna prefers the slower currents along river banks in dense vegetation. In the Rainbow River, Florida, P. concinna spends much of its time in the submergent and emergent vegetation along the sides of the streambed. Large specimens are found more often in deeper water, usually with eddying or very slight currents, at 5-6 m depth (Ward 1980).

Pseudemys c. suwanniensis from the Suwannee River forage in the Manatee Springs Run, Florida, but do not remain in the spring or the run except for short periods (Ward 1980). In the Chipola River, Florida, the largest $P$. concinna specimens were found in cuts about 5-6 m deep. Pseudemys tried to hide rather than swim away as did Graptemys. In the Yellow River, Florida, mediumsized specimens were found in holes 1-3 m deep. In the Conecuh River, Alabama, P. concinna was found only in deeper holes along bank undercuts with fallen logs ( $\mathbf{J}$. Ward, pers. obs.). Jackson (2002) noted that $P$. concinna populations in several small rivers along the Florida Gulf Coast occurred mostly in the lower reaches that received abundant sunshine; canopied sections upstream harbored few or no cooters.

Ward (pers. obs.) found western populations utilizing a variety of habitats, both moving and still, shallow and deep water. All occurrences were in rivers or streams, in catch basins in streambeds of intermittent flowing streams, or in reservoirs derived from, or adjacent to, previously unrestricted rivers.

By most accounts, $P$. concinna is almost exclusively herbivorous (Lagueux et al. 1995; Jackson and Walker 1997), with a diet of aquatic plants. Morphology of the skeletal and muscular elements of the jaw mechanism seems to reflect this (Mahmoud and Klicka 1979; Ward 1980, 1984). Ward (1980) examined contents of stomachs of specimens collected in September, October, December, and May from the Rainbow and Chipola rivers and Manatee Springs Run, Florida, and found that aquatic plants, principally Sagittaria, accounted for nearly $95 \%$ of the contents. Buhlmann and Vaughan (1991) reported the primary food source of adults as aquatic macrophytes in the New River, West Virginia. Lagueux et al. (1995) recorded a variety of aquatic macrophytes and algae in the stomachs of a series of P. concinna from the Wakulla River, Florida. River cooters may be active year-round in warmer climates, such as peninsular Florida, but activity is much reduced in colder climates. Nonetheless, Ward (pers. obs.) observed an active individual in January beneath $5 \mathrm{~cm}$ of surface ice in a pond at 1130 hours when outside air temperature was $-1.0^{\circ} \mathrm{C}$.

Buhlmann and Vaughan (1991) observed basking in the New River population from March - September, from 0815-1715 hrs; basking occurred when air temperature was warmer than water temperature. Pritchard and Greenhood (1968) found $P$. concinna basking in Florida between 0710-1645 hrs, with peak activity at $1200 \mathrm{hrs}$. Juveniles commonly bask on the branches of snags fallen into the water in many Florida rivers (Jackson, Ward, pers. obs.). Hutchinson (1979) recorded $41.8^{\circ} \mathrm{C}$ as the lethal critical temperature for $P$. concinna in the laboratory. 
The period of courtship in nature is poorly known for this species. In the Chipola River, Florida, Ward (pers. obs.) recorded copulation in October. Copulation occurred in long, wide stretches of the river where the current was slower. Courtship in P. c. suwanniensis was discussed by Jackson and Davis (1972), and courtship-like activity in juveniles identified as $P$. c . concinna was described by Petranka and Phillippi (1978).

Throughout its range, $P$. concinna nests in the late spring and early summer, with May and June being the peak months; nesting may begin in late March or early April in warmer climates, such as northern Florida. Multiple clutches are common, with as many as four or more clutches being produced at roughly three-week intervals by females in Florida (Jackson and Walker 1997).

Nests are generally constructed in friable, sandy soils where available. Females may nest along sandbars and banks immediately adjacent to water, or may travel $200 \mathrm{~m}$ or more to locate sites. The species is highly unusual in that females dig shallow accessory holes on either side of the larger, central nest chamber; this trait is shared only with $P$. floridana. From zero to three eggs may be laid in each of the accessory holes. The accessory holes presumably play a role in predator deterrence (Jackson and Walker 1997).

Ewert (1979) and Jackson and Walker (1997) described $P$. concinna eggs, including weight, linear dimensions, and shell thickness. Eggs (12-20 g) and hatchlings are small relative to maternal body size $(5-10 \mathrm{~kg})$, with clutch mass approximating $5 \%$ of female body mass (Jackson and Walker 1997). Average clutch size varies from 9-20 in various populations throughout the species' range (Jackson and Walker 1997).

Development rate of eggs is temperature-dependent, with hatching occurring in 70-90 days at typical nest temperatures. Incubation temperatures determine the sex of developing embryos (Jackson and Walker 1997), with the result that the female: male hatchling sex ratio increases with degree of exposure of the nest to the sun. Hatchlings may emerge from the nest either in the fall or during the spring following overwintering in the nest (Jackson 1994). Emergence from the nest presumably follows soil temperatures and perhaps moisture levels.

Population densities in the individual pools of the New River, West Virginia, were estimated at 1.0-2.3 per ha, with a male: female ratio of 1.9:1.0, with greatest population densities occurring in areas of dense aquatic vegetation (Buhlmann and Vaughan 1991). Jackson and Walker (1997) estimated a standing population of 61 adult females (390 $\mathrm{kg}$ ) per $\mathrm{km}$ of river and 7.4 adult females $(48 \mathrm{~kg}$ ) per ha of surface water in the Wakulla River, Florida. Bury (1979) noted that Jackson (1970) found a male-female ratio for $P$. concinna of 1.15 in another Florida spring-run stream.

Two radiotagged specimens in the New River, West Virginia, had home ranges of 1.2 and 1.6 ha, respectively (Buhlmann and Vaughan 1991). Jackson and Walker (1997) estimated linear home ranges of 200-600 m for four radiotagged adult females in the Wakulla River, Florida.
Belkin (1964) described episodic breathing in $P$. concinna that consisted of a rapid series of breaths, followed by apnea; this allows turtles to tolerate dives of 2-3 hrs duration. Jackson (1979) noted two features of the respiratory properties of the blood of $P$. concinna: a low hematocrit and a high carbon dioxide content.

Teehan and Short (1989) found that river cooters collected in areas of infected snails also carried Spirorchis innominata. Shell diseases of undetermined cause are known in at least two populations of river cooters. A severe shell disease affects a large percentage of the river cooter population (as well as sliders) in one Georgia impoundment (Lake Blackshear, Flint River: Lovich et al. 1996; Garner et al. 1997). The river cooter is also one of six species of aquatic turtles reported to suffer from shell disease in a Virginia river (Ernst et al. 1999). Such occurrences suggest the possible role of pollutants in causing initial damage to turtles or their immune systems, which then allows invasion by microorganisms that may cause greater damage or even death.

Population Status. - Most populations seem to be flourishing or at least stable, although there is little information regarding population sizes or dynamics. Western populations do not appear to be as dense in numbers as those in the eastern parts of the range. At the one site in Florida (Rainbow River, Marion County) with long-term data, the population seems to have declined substantially over the last 60 years, although there are signs of a slight recent rebound (Huestis and Meylan 2004).

Threats to Survival. - Stream pollution from chemical runoff, and siltation due to soil erosion from changes in land use along rivers, appear to be the greatest active threats to survival. Besides possible direct impacts on $P$. concinna, the effects of pollution on aquatic vegetation may have secondary impacts on cooter populations dependent upon plants for food. Potentially, diversion of harvest from Trachemys to Pseudemys for scientific supply houses may have a great impact in the near future. In the south, a limited number are taken for food by local residents; some of this almost certainly constitutes illegal harvest (several documented instances in Florida, where possession is restricted). The current massive export of turtles to Asian food markets also poses a potential threat to this species, which could be harvested commercially in large numbers if regulations and their enforcement are insufficient As with most turtles, predation affects all life stages, from juveniles to adults, but information regarding any recent increase in predation on cooter populations has not been forthcoming to date.

Conservation Measures Taken. - With one exception, neither state nor federal statutes protect $P$. concinna specifically, although some protection is provided through general game or wildlife regulations (including recent regulations in North Carolina and Texas). The exception is Florida, which restricts but does not prohibit harvest of the species as well as lists the subspecies $P$. $c$. suwanniensis as a Species of Special Concern. Without further data on the status of $P$. concinna populations, 
proposals to protect this species elsewhere would seem premature.

Conservation Measures Proposed. - No specific regulatory proposals currently address this species. Nonetheless, numerous land and river protection efforts are ongoing in the species' range, and these would promote its conservation. In Florida alone, current proposals seek protection for several rivers (e.g., Perdido, Yellow, Ochlockonee) that are inhabited by the species.

Captive Husbandry. - Pseudemys concinna does well in captivity and can even be found regularly in the collections of European turtle hobbyists. Although inclusion of some native aquatic plants is desirable, individuals of all ages will usually eat lettuce and green leafy vegetables (including grass as well). Romaine lettuce appears to be more nutritious or more efficiently digested than other varieties. Younger specimens thrive on dried or canned dog food, trout and catfish chow, or cat food. Many will eat fish, chicken, and red meat. Hatchlings require abundant sunshine or extended exposure to a regular incandescent light bulb to maintain body temperature and induce vitamin D formation necessary for proper calcium metabolism. Specimens of $P$. concinna generally ignore or tolerate other species in the same enclosure with little obvious interaction.

If specimens are allowed to rest directly on the bottom of a container with non-filtered water, their plastra will often become infected with bacteria, fungi, and algae. A layer of mud, sand, or gravel on the bottom, or continuously circulating filtered water, avoids this problem. If untreated, scutes will flake off and bone will become exposed. Constant treatment with bactericides, preservatives, and other sterilants may be attempted to control infections, although such treatments may become ineffective with time. Internal infections of bacteria or other parasites usually have little effect on the overall health of specimens, although in more severe cases, treatment with antibiotics or vermicides is appropriate. However, certain parasites that attack the liver or kidneys can be fatal. Moreover, many universally accepted treatments for other animals can be fatal to turtles, including Pseudemys.

Eggs can be collected, even if laid in water, and incubated with excellent results, providing the eggs are recovered soon after laying. Depending on temperature, incubation in captivity may take 70-110 days. Greater than $90 \%$ hatching success can be achieved by keeping eggs in damp newspaper, vermiculite, or clean sand.

Current Research. - Although a summary of results to date has been recently published (Huestis and Meylan 2004), the long-term population and demographic study directed by P. Meylan on the Rainbow River, Florida, continues and promises to increase our knowledge of turtle demographics. D. Jackson continues occasional monitoring of nesting in the Wakulla River, site of the most extensive reproductive study of the species (Jackson and Walker 1997), and is now gaining long-term data on the reproductive lives of female river cooters (Jackson 2003).
With the abundance of suitable populations of this wide-ranging species, it is surprising that more research has not been done. Such information is sorely needed to ascertain its regional and local status and the effects of human cultural waste products and manipulations of habitats on its populations.

Acknowledgments. - Jackson's studies of the species in Florida have been supported in part by grants from the Florida Fish and Wildlife Conservation Commission, Chelonian Research Foundation, and the Chelonia Institute, as well as by sabbatical leave provided by The Nature Conservancy.

\section{LITERATURE CITED}

Agassiz, L. 1857. Contributions to the Natural History of the United States of America. First Monograph. Volume I. Part I. Essay on Classification. Part II. North American Testudinata. Boston: Little, Brown and Co., pp. 1-452.

BELKIN, D.A. 1964. Variations in heart rate during voluntary diving in the turtle Pseudemys concinna. Copeia 1964(2):321-330.

BRIMLEY, C.S. 1928. Two new terrapins of the genus Pseudemys from the southern states. J. Elisha Mitch. Sci. Soc. 44:66-69.

Buhlmann, K.A. and Vaughan, M.R. 1991. Ecology of the turtle Pseudemys concinna in the New River, West Virginia. Journal of Herpetology 25(1):72-78.

BURY,R.B. 1979.Population ecology of freshwater turtles.In: Harless, M. and Morlock,H.(Eds.).Turtles: Perspectives and Research.New York: John Wiley and Sons, pp. 571-602.

Conant, R. And Collins, J.T. 1991. A Field Guide to Reptiles and Amphibians of Eastern and Central North America. Third Edition. Boston: Houghton Mifflin Co., 450 pp.

Dixon, J.R. 1987.Amphibians and Reptiles of Texas. College Station: Texas A\&M University, 434 pp.

DuMÉRIL, A.M.C. AND BIBRON, G. 1851. [Emys labyrinthica]. In: Duméril, A.M.C. and Duméril, A.H.A. Catalogue Methodique de la Collection des Reptiles (Museum d'Histoire Naturelle de Paris). Paris: Gide and Baudry, $224 \mathrm{pp}$.

DundeE,H.A. And Rossman,D.A. 1989. The Amphibians and Reptiles of Louisiana. Baton Rouge: Louisiana State Univ. Press, 300 pp.

ERnst, C.H. 1990. Pseudemys gorzugi. Catalogue of American Amphibians and Reptiles 461:1-2.

ERnst, C.H., Akre, T.S.B., WilgenbusCh, J.C., Wilson, T. P., AND K. Mills. 1999. Shell disease in the Rappahannock River, Virginia. Herpetological Review 30:214-215.

ERnst, C.H. AND BARBOUR, R.W. 1989. Turtles of the World. Washington, DC: Smithsonian Institution Press, $313 \mathrm{pp}$.

EWERT, M.A. 1979. The embryo and its egg: development and natural history.In:Harless,M.andMorlock,H.(Eds.).Turtles: Perspectives and Research. New York: John Wiley and Sons, pp. 333-413.

FRost, D.R. AND HILLIS, D.M. 1990. Species in concept and practice: herpetological applications. Herpetologica 46(1):87-104.

Garner,M.M.,HerRington,R.,Howerth,E.W.,Homer, B.L.,Nettles, V.F., IsazA, R., Shotts, E.B., JR., AND JAcobson, E.R. 1997. Shell disease in river cooters (Pseudemys concinna) and yellow-bellied turtles (Trachemys scripta) in a Georgia (USA) lake. Journal of Wildlife Diseases 33:78-85.

GraY, J.E. 1830. A synopsis of the species of the Class Reptilia. In: Griffith,E. and Pidgeon,E. (Eds.). AClassified Index and Synopsis of the Animal Kingdom Arranged in Conformity with its Organization, by the Baron Cuvier, with Supplementary Additions to each Order. Vol. 9. London: Whittaker, Suppl: 110pp.

HoLbROOK, J.E. 1836. North American Herpetology; or, a Description of the Reptiles Inhabiting the United States. Ed. 1, Vol. 1. Philadel- 
phia: J. Dobson, 120 pp

HolBROOK, J.E. 1838. North American Herpetology; or, a Description of the Reptiles Inhabiting the United States. Ed. 1, Vol. 2. Philadelphia: J. Dobson, 125 pp.

Huestis, D.L. and Meylan, P.A. 2004. The turtles of Rainbow Run (Marion County, Florida): observations on the genus Pseudemys. Southeastern Naturalist 3:595-612.

Hutchison,V.H.1979.Thermoregulation.In:Harless,M. and Morlock, H. (Eds.). Turtles: Perspectives and Research. New York: Wiley and Sons, pp. 207-228.

IVERSON,J.B. 1992.ARevised Checklist with Distribution Maps of the Turtles of the World. Richmond, IN: Privately Printed, 363 pp.

JACKSON, C.G., JR. 1970. A biometrical study of growth in Pseudemys concinna suwanniensis. I. Copeia 1970(3):528-534.

JACKSON, C.G., JR. AND DAVIS, J.D. 1972. Courtship display behavior of Chrysemys concinna suwanniensis. Copeia 1972:385-387.

JACKSON, D.C. 1979. Respiration. In: Harless, M. and Morlock, H. (Eds.). Turtles: Perspectives and Research. New York: Wiley and Sons, pp. 165-191

JACKSON, D.R. 1994. Overwintering of hatchling turtles in northern Florida. Journal of Herpetology 28:401-402.

JACKSON,D.R. 1995. Systematics of the Pseudemys concinna-floridana complex (Testudines: Emydidae): an alternative interpretation. Chelonian Conservation and Biology 1:329-333.

JACKSON, D.R. 2002. Survey of an important distributional "gap" in the Florida range of the river cooter and other freshwater turtles. Florida Fish and Wildlife Conservation Commission, Tallahassee.

JACKSON, D.R. 2003. Pseudemys concinna suwanniensis (Suwannee Cooter). Reproduction, life span. Herpetological Review 34:363.

JACKSON, D.R. 2006. Pseudemys concinna - river cooter. In: Meylan, P.A. (Ed.). Biology and Conservation of Florida Turtles. Chelonian Research Monographs No. 3, pp. 325-337.

JACKSON,D.R.ANDWALKER,R.N.1997.Reproduction in the Suwannee cooter, Pseudemys concinna suwanniensis. Bulletin of the Florida State Museum, Biological Sciences 41:69-167.

Lagueux, C.J., Bjorndal, K.A., Bolten, A.B., and Campbell, C.L. 1995. Food habits of Pseudemys concinna suwanniensis in aFlorida spring. Journal of Herpetology 19:122-126.

Le ConTe, J. 1830. Description of the species of North American tortoises. Annals of the Lyceum of Natural History, New York 3:91-131.

Lovich,J.E., Gotte, S.W.,ERnst, C.H.,Harshbarger, J.C.,LAemmerZAHL,A.F., AND GIBBONS, J.W. 1996. Prevalence and histopathology of shell disease in turtles from Lake Blackshear, Georgia. Journal of Wildlife Diseases 32: 259-265.

MaHMoud, I.Y. AND KLICKA, J. 1979. Feeding, drinking and excretion. In: Harless, M. and Morlock, H. (Eds.). Turtles: Perspectives and Research. New York: Wiley and Sons, pp. 229-243.
Meylan,P.A.(Ed.).2006.Biology and Conservation of Florida Turtles Chelonian Research Monographs No. 3,376 pp.

Moll, E.O. 1979. Reproductive cycles and adaptations. In: Harless, M. and Morlock, H. (Eds.). Turtles: Perspectives and Research. New York: Wiley and Sons, pp. 305-331.

PetranKa, J.W. AND PhillipPI, A. 1978. Observations on the courtship behavior of juvenile Chrysemys concinna concinna and Chrysemys floridana hoyi (Reptilia, Testudines, Emydidae). Journal of Herpetology 12(3):417-419.

PritchaRd, P.C.H. AND GREENwOOd, W.F. 1968. The sun and the turtle. International Turtle and Tortoise Society Journal 2(1):20-25,34.

SEIDEL, M.E. 1994. Morphometric analysis and taxonomy of cooter and red-bellied turtles in the North American genus Pseudemys (Emydidae). Chelonian Conservation and Biology 1:117-130.

SeIDEL, M.E. AND DRESLIK, M.J. Pseudemys concinna (Le Conte), river cooter. 1996.Catalogue of AmericanAmphibians and Reptiles 626.1626.12. Society for the Study of Amphibians and Reptiles.

SeIDEl, M.E. AND PaLmer, W.M. 1991. Morphological variation in turtles of the genus Pseudemys (Testudines: Emydidae) from Central Atlantic drainages. Brimleyana 17:105-135.

TEEHAN,W.H. ANDSHORT, R.B.1989.Mitotic chromosomes of a species of Spirorchis (Trematoda: Spirorchiidae). Journal of Parasitology 75(3):474-476.

THOMAS, R.B. AND JANSEN, K.P. 2006. Pseudemys floridana - Florida cooter. In: Meylan,P.A.(Ed.). Biology and Conservation of Florida Turtles. Chelonian Research Monographs No. 3, pp. 338-347.

WARD, J.P. 1980. Comparative cranial morphology of the freshwater turtle subfamily Emydinae: an analysis of the feeding mechanisms and systematics. PhD. Thesis, North Carolina State University, Raleigh.

W ARD,J.P. 1984. Relationships of chrysemyd turtles of North America (Testudines: Emydinae). Special Publications of the Museum of Texas Tech University 21:1-50.

WIED, M.zU. 1865. Verzeichniss der Reptilien, welche auf einer Reise im nördlichen America beobachtet wurden. Nova. Acat. Acad. Leopold Carol. Nat. Curios 32:1-143.

\section{Citation Format for this Account:}

WARD, J.P. AND JACKson, D.R. 2008. Pseudemys concinna (Le Conte 1830) - river cooter. In: Rhodin, A.G.J., Pritchard, P.C.H., van Dijk, P.P., Saumure, R.A., Buhlmann, K.A., and Iverson, J.B. (Eds.). Conservation Biology of Freshwater Turtles and Tortoises: A Compilation Project of the IUCN/ SSC Tortoise and Freshwater Turtle Specialist Group. Chelonian Research Monographs No. 5, pp. 006.1-006.7, doi:10.3854/ crm.5.006.concinna.v1.2008, http://www.iucn-tftsg.org/cbftt. 